\title{
Vernacular Architecture: A Term Denoting and Transporting Diverse Content
}

\author{
Klaus Zwerger \\ Vienna University of Technology, Vienna, Austria \\ Email: zwerger@gestaltungslehre.tuwien.ac.at
}

\begin{abstract}
A selective review of the literature demonstrates the difficulty in defining 'vernacular architecture'. Recent studies have presented an overly narrow, single-sided, or even unacceptable image of the topic in comparison with many earlier definitions and discussions. However, those earlier analyses also had various shortfalls. The interdependence of vernacular architecture, economic interests, and emerging awareness of buildings' interaction with the environment demand a rethinking of vernacular architecture, which the present study understands as signifying housing offered for most of the world's population.
\end{abstract}

KEYWORDS vernacular architecture, interdependence, resource scarcity, changed expectations

Received February 26, 2019; accepted December 17, 2019.

\section{Introduction}

Christopher Alexander commences his famous book The Timeless Way of Building with an explanation of his understanding of 'The Timeless Way': 'It is a process which brings order out of nothing but ourselves; it cannot be attained, but it will happen of its own accord, if we will only let it' (1979, ix). After the publication of numerous articles and book chapters on vernacular architecture over recent decades, this trusting conviction does not need any further comment. Alexander's leitmotiv provides an indissoluble connection among vernacular architecture, sustainability, and timelessness (cf. AlSayyad and Arboleda 2011, 137).

Those three terms open up a spectrum that is not even remotely comprehensible. Therefore, the present paper considers three questions related solely to the term 'vernacular architecture'. (1) Is it possible to define 'vernacular architecture'? Different and sometimes contradictory notions characterise scholarly contributions on the topic. (2) What are the weak points in the contemporary discourse on the subject? My review of the arguments aims at integrating considerations on the potentialities of vernacular architecture in the current context of change. This leads to the final question: (3) What tasks do I personally see in the term? My contribution aims at providing an idea of the following: the difficulty in comprehending the term 'vernacular architecture'; the degree to which its interpretation can be rooted in scholars' affiliations in their disciplines; and finally, owing to current demands, it is necessary to rethink vernacular architecture.

\section{Characterisation of Vernacular Architecture in the Literature}

Prominently and proactively, Rapoport and Oliver tried to identify the fundamental principles that characterise vernacular architecture. Subsequently, many authors and architects have selected certain aspects for use as catchwords: perhaps that was as a countermovement to an architectural approach that has been strongly determined by industrial forces and has changed the image of architecture around the world. This change went hand in hand with social upheavals and reckless exploitation of natural resources. Many authors (cf. Vellinga 2013) drew wrong conclusions or made untenable assertions. It could be that they were under pressure from large numbers of clients who enjoyed the benefits of contemporary architecture with its industrial character but were confronted with (Larsson 1989, 518-524) or felt subjected to its deficits (Vellinga 2011, 176-77).

Apart from the above-mentioned originators, many more influences have established and cultivated an image 
of vernacular architecture that is seemingly devoid of all shortfalls. Examples are open-air museums and cultural heritage sites (cf. AlSayyad 2001; Hamza 2019; Mugerauer 2001; Robinson 2001). Beyond their economic success story, we must not forget that their showcasing has detracted from their authenticity as examples of vernacular architecture. Here, it is not just a question of whether they are credible representatives of such architecture. Ultimately, their relentless economic exploitation could even stir national sentiments in different countries in the competition for heritage sites (AlSayyad 2001, 16; Illich 1982, 119; Oliver 1989, 2001; Upton 2006/07, 9). A reflexive look back to a time that allegedly had answers to all tasks and problems and thus becomes interpreted as the 'good old days' (cf. Sauerbruch and Hutton 2011, 45) highlights political tendencies that promise to preserve what has been lost. Sections of the population that cannot follow the speed of change tend to be averse to changes that come from outside; they wish to rebuild their heritage in seclusion. Vernacular architecture was earlier regarded as a refuge of regional and national sentiments (Brunskill $1971,18)$ as well as a convenient symbol for national and subnational identities (Brown and Maudlin 2012, 352 quoting Leach 2002). I do not deal with these considerations in detail, but I wish to provide an idea of the range of impacts when reflecting on this paper's first question.

I access the topic as a craftsman and scholar. As a craftsman, I am fascinated by analytic observations of historic buildings and building techniques. I believe I am able to read in such observations ideas for innovative approaches in addressing current tasks. Beyond such practical considerations, I am convinced that documenting a vanishing built culture contributes to historiography. This may disrespectfully be described as pointless support of a fundamentally changing identity or as the romantic production of photographs and drawings (exaggerating AlSayyad 1989, 531). It is incontestable that written and pictorial documentation cannot replace the loss of structural knowledge-regardless of whether the knowledge concerns manual skills, properties of materials, or workflows. In contrast to Tuan (1989, 33), I am convinced that skills and knowledge not applied are not transmitted and become lost ${ }^{1}$. I also do not agree with Maudlin that my 'archaeological approach to research ... suggests a deeper conviction that vernacular architecture is best understood in terms of structures because those structures are, or were, functionally determined' (2010, 10). Maudlin's point is correct but insufficient. If I want to understand a structure in all its details, I have to talk to the people living in it and-optimally-with the person responsible for its construction. Selecting, collecting, and transporting materials, preparing the structural elements, and the processes of construction and furnishing are social, economic, cultural, and material processes that are embedded in cultural traditions.

'Research on dwelling traditions belongs ... no more to architecture than to anthropology, archeology, geography or art and architecture history - to name just a few' (Bourdier 1989, 36). It is impossible to separate a house providing physical shelter from the dweller in the house: that is the person who lives and works in the house and gives it an identity. As a scholar, I am fascinated with the ongoing realisation that no discipline by itself is able to offer valid explanations for all buildings. All disciplines have to listen and be well advised to be aware that we always put 'ourselves in context' (AlSayyad 1989, 531 quoting Spiro Kostof). Normative explanations are outdated. Avoiding discussion with other people tends to lead to entrenched opinions: it does not benefit the main task of architecture, which is that of serving human needs.

According to Upton, 'vernacular architecture' was first used in the $19^{\text {th }}$ century by architectural theorists. They referred to the preindustrial buildings of yeoman farmers as being devoid of 'the intellectual and artistic currents of the Renaissance' (Upton 1983, 262; cf. Vellinga 2011, 176).

Most will agree that the term 'vernacular' expresses usage in everyday life by ordinary people in a particular region. Thus, 'vernacular architecture' can be defined as 'architecture built of local materials to suit particular local needs, usually of unknown authorship and making little reference to the chief styles or theories of architecture' (GRI 2018). 'Chief styles' refers to architectural expressions and designs that characterise a representative architecture over a specific period of time span regardless of whether it is religious or secular. The delimitation is ultimately less strict than it may appear. Rapoport states that the high style of architectural elements 'can be fully and properly understood only in the context of the vernacular matrix which surrounded them, and to which they were related, at the time they were created' (1980, 283).

However, problems arise with respect to public structures, such as schools, governmental buildings, opera houses, and prisons. Then, it is not so clear whether they should be regarded as vernacular architecture. Maudlin employed the terms 'polite' and 'vernacular' when distinguishing types of architecture, stating that 'the boundary is inherently porous' (2010, 10; cf. Brunskill 1971, 25-28). Vernacular architecture is 'formed out of historic professional, academic and social constructs' (Brown and 
Maudlin 2012, 345). A created 'other' - 'most evident in the delineation of cultural and ethnic boundaries'-ultimately supports intellectual imperialism (Brown and Maudlin 2012, 352; cf. Upton 1993, 10-11). Separating Western from non-Western cultures was an attribution of 'otherness' that had long historical roots (Upton 1993, 10). With the adoption of a broader perspective beyond Europe and North America (Vellinga 2006, 84; Vellinga $2013,583)$, this separation became inappropriate with respect to 'modern' versus 'rooted in tradition' (Brown and Maudlin 2012, 349).

In 1964, the still 'unfamiliar world of nonpedigreed architecture' had to resort to the terms 'vernacular, anonymous, spontaneous, indigenous, rural, as the case may be,' simply 'for want of a generic label' (Rudofsky 1964). There are still more designations. Özkan gives a brief explanation of the various terms $(2006,100)$. According to Noble, the term 'vernacular' was widely used in the United Kingdom, whereas 'traditional' was preferred in North America $(2007,6)$. Anthropologists urged replacement of the negatively connoted term 'primitive'. I refer to discussions of the underlying meaning by Guidoni (1994, 5-15) or Rapoport (1990, 26-27). Among other factors, Tuan questioned use of the term 'traditional' because it explicitly emphasizes a lack of creativity and choice (1989, 27-33).

There is also the definition given by Aalen, an Irish cultural geographer; it intends to specify and thus narrow the content of the term 'vernacular': 'Conformity, anonymity, and continuity may be seen as the hallmarks of regional vernacular architecture, reflecting the cultural coherence, simplicity, and conservation of present communities and the deep rooted traditions within the building craft' (1973, 27). It is necessary to examine the descriptive terms carefully. I wish to emphasise that the terms initially employed in this subject area underline how difficult it is to arrive at valid definitions. When related to traditional villages, conformity is a valued characteristic: houses are regarded as fitting with another just as they fit with their environment. 'Individual expression is of small importance in vernacular shelter, for the similarity of the buildings within a cluster is symbolic of identification with the group that resides within them.' (Oliver 1975, 12) Not all would agree with Oliver. Lewcock demonstrates how houses may at first glance appear identical but in reality are not $(2006,203)$. That is in contrast to groups of houses in modern towns, which are examples of overemphasis of economic efficiency. Rapoport introduces examples of anonymous architecture whose designers are not anonymous $(1989,89)$. Lack of knowledge can easily lead to wrong assumptions.
Continuity does not express rigid immutability or constant repetition: it is adherence to social rules that ensures a community's cohesion. Those rules were adapted to societal change and many influencing conditions, such as inherent quality. Quality does not straightforwardly refer to building or material quality; it refers to integrating experience, knowledge about the climate, geography, building materials, treatment of materials, and social solidarity as well as to dependence, cultural embedding, and inhabitants' well-being.

The above characterisation 'results in representations of vernacular traditions that are frozen in time, incomplete and, quite often, romanticised' (Vellinga 2006, 83). Consequently, Vellinga replaces the term 'vernacular architectures' with 'vernacular traditions', defining tradition as 'a conscious and creative adaptation of past experience to the needs and circumstances of the present' (Vellinga 2006, 83). Vellinga's approach certainly facilitates the perception of vernacularity as a dynamic process. Kopytoff emphasised the processual character of all kinds of buildings being driven by the continuous change in their use, function, and meaning (1986). Similarly unhappy with an overly narrow interpretation, other authors included more broader conceptions. Brown and Maudlin added the category 'everyday'-material culture as an artifact of human culture (2012, 341). Upton protested, 'We tend not much to have to say about the truly ordinary or about the seamier aspects of our buildings or builders. Our tale is relentlessly cheerful' (Upton 2007, 9; a variation of an earlier statement, 1993, 14). This is a savage contradiction to the often miserable living conditions of those living in such buildings.

Obviously, deficiency of clarity is unacceptable. 'Lack of definition and explanation [of vernacular architecture] ... may ... suggest a certain academic laziness on the side of the scholars concerned'; that results in perpetuating generalised, stereotypical images (Vellinga 2013, 583). Vellinga's concluding statement that 'vernacular architecture is nothing more or less than the architecture of the Other' $(2011,172)$ is as provocative as Pritzker prize winner Hans Hollein's dictum that 'everything is architecture'. However, it is necessary to identify the terms that are used to characterise this 'architecture of the Other'.

\section{Critical Comments on Recent Literature on Vernacular Architecture}

The enormous growth in scholarly interest in vernacular architecture has led authors to make simplifications, inaccurate statements, and wrong conclusions, which has driven worldwide discussion. In doing so, researchers 
have overextended themselves and denounced methodical weaknesses to which they themselves fall victim.

The way some authors have pounced on Bernard Rudofsky appears almost like a witch hunt (AlSayyad and Arboleda 2011, 137; Maudlin 2010, 10; Upton 1993, 12; Vellinga 2011, 182; 2013, 581-82). Özkan is one of the few who defended Rudofsky instead of simply quoting him: 'He provokingly brought to the fore and introduced onto the agenda of world architecture an area of architecture that had, as yet, gone largely unnoticed and which used to belong solely to a rather hidden field of academic architectural research.' $(2006,99)$

Rudofsky tried to open his colleagues' eyes: he attempted to free them from their one-dimensional perception of architecture. As an architect, Rudofsky employed a language that was most likely to be used by his peers: an 'essentially aesthetic approach' (Vellinga 2011, 282). Thus, Rudofsky intends to set other architects thinking more effectively. The exhibition and associated publication Architecture without Architects (1964) made him famous. Everyday architecture ignored his wake-up call. The criticism of the authors cited in the previous paragraph is accurate, but it hits the wrong. Authors should be denounced if today they cite a book like Rudofsky's that has become a synonym for a particular idea but which is seldom read carefully. No one pillories anthropologists when they long believed that there was little more in vernacular architecture than fireplaces, sleeping places, and place hierarchies. Rudofsky was unpleasant in many respects. He made his colleagues' conceitedness, Eurocentrism, their biased perception of architectural history and social components a subject of discussion. The choice of the pictures presented in Architecture without Architects was not just selective; it was tendentious.

Rudofsky used his photographic material first and foremost to provoke his colleagues: 'Vernacular architecture does not go through fashion cycles.' 'The untutored builders in space and time ... demonstrate an admirable talent for fitting their buildings into the natural surroundings.' 'They welcome the vagaries of climate and the challenge of topography.' 'Part of our troubles results from the tendency to ascribe to architects ... exceptional insight into problems of business and prestige.' 'It is the humaneness of this architecture that ought to bring forth some response in us.' All these statements are directed at architects, and simultaneously they contain a hidden message at consumers of architecture for treading on architects' toes. Such consumers hold the lever to remind architects that their products are not primarily intended as tools of narcissism.
I now move to a broader point of criticism. Vellinga's meticulous collection of 175 studies convinced him that 'reductionist and essentialist approaches' might 'ultimately hinder the integration of vernacular traditions in contemporary design rather than encourage and enable it' $(2013,572)$. He refers to a skeptical article of AlSayyad and Arboleda (2011) that does, what Vellinga argues: 'Selected ... from a large number of building traditions' that are 'lumped together to underscore and illustrate certain points or arguments that apparently' shall discredit more or even all (Vellinga 2013, 582). The quoted article's authors structure their verification of identified 'repeatedly invalid ... sustainability principles' in 'material and site appropriateness', 'climate responsiveness', 'socio-economic advantages', and 'adaptability'.

AlSayyad and Arboleda claim to be able to refute material and site appropriateness with examples. At first glance, they appear to be correct. Material and site appropriateness are commonly linked with ideals: they did not exist in various regions for centuries-not only since the $20^{\text {th }}$ century (as in the examples of AlSayyad and Arboleda). In South China and in border regions to adjoining countries, flight and expulsion have shaped the narratives of minority peoples (e.g., Wiens 1954). Repeatedly, people there had to readapt their old building traditions by use of locally available materials and according to locally specific conditions; therefore, they were site appropriate. That issue increased dramatically in the second half of the $20^{\text {th }}$ century. Following international pressure to strictly determine borders, many governments used the opportunity to force their minority peoples to settle permanently in certain locations. Such minorities had previously been difficult to govern: they sought better living conditions and ignored borders they regarded as randomly defined (cf. Scott 2009). Minorities became accused of destroying environments using slash-and-burn cultivation. That assertion was and still is one of the main arguments used in forcing them to settle down ${ }^{2}$. Meanwhile, there is ample scientific evidence indicating that such insinuations are questionable and economically motivated (e.g. Berkes 1999; Cairns 2007; Choocharoen 2014; Hecht, Morrison and Padoch 2014; Parrotta and Trosper 2012; Yokoyama et al. 2014). Some of the minority peoples investigated have built fascinating complex buildings (e.g. Zwerger and Mallikamarl 2019) as well as simple huts. Despite having to deal with flight and expulsion, they used only locally available materials. Examples of such use in refugee camps are very clear: refugees employ only locally available materials-even if they amount just to cardboard, sheet metal, 
or waste materials. In order to sound not disparaging, such construction should be termed 'site adapted' rather than 'site appropriate'.

AlSayyad and Arboleda call Malinowski, Fortune, Mead, and Bateson for assistance to confirm their view (AlSayyad, Arboleda 2011, 142). It is little wonder that Malinowski, Fortune, Mead, and Bateson emphasise social conditions and draw conclusions from their viewpoint. Architects and building historians focus on different targets (cf Oliver 1987, 9). Questions that need to be addressed are as follows: Which material was used when and for what purpose? Are the used materials and the way of employment environmentally less harmful than contemporary materials? To demonstrate that I am aware of the complexity of this topic, I add here two examples of how the use of a material cannot be taken as a proof for anything. The alleged 'green' material wood can (and unfortunately quite often is) abused as a coverup-thoughtlessly, unconsciously, or even consciously. 'So-called sustainable timber buildings of recent years have turned out to be hollow, when viewed against their initial claims of environmental sensitivity.' (Røstvik 2011, 178, with reference to Norway) The experience of fire burning down whole villages could lead to the decision to substitute wood as a building material for stone (Zwerger 2012, 185). But such a change could happen only locally and depending on the availability of the newly chosen material.

The question cannot be whether we should build today as we did for centuries in the past. The question has to be as follows: what ecologically, socially, and culturally acceptable result could emerge from the relationship-building task at a designated location and with reference to historical examples of vernacular architecture? The evidence of AlSayyad and Arboleda indicating that material and site appropriateness are false assumptions may be interpreted in different ways. Vernacular architecture represents a flexible approach to construction such that in certain cases, 'social conventions, gender roles and the economic functions of buildings' (AlSayyad, Arboleda 2011, 14243); they supplant building forms optimally adapted to a site or materials. This flexibility is no weakness; still less is it a reason to abandon vernacular architecture.

AlSayyad and Arboleda offer examples in order to demonstrate that climate responsiveness is no longer accurate (143-46). Many structural responses to climatic challenges developed over centuries: they were long beneficial even if that is no longer the case. Yet, many buildings constructed over recent decades demonstrably lack suitability. It has become evident (primarily in urban agglomerations) that buildings made of concrete and glass raise questions much sooner than with the structures of the former vernacular architecture. Foruzanmehr and Vellinga took a further step by including social considerations (2011). They discuss wind catchers as architectural installations for cooling the inner temperatures of dwellings. For the average consumer, wind catchers may not be able to compete with air-conditioners and electromechanical cooling systems. However, it has been argued that one should reconsider un-reflected habits. The building sector consumes almost $40 \%$ of total primary energy use (Logue et al. 2013). The energy required for space cooling and ventilation is a rising energy consumption factor (Isaac and van Vuuren 2009). The air-conditioner market is growing worldwide (Chiesa and Grosso 2016). The Chinese market is showing exceptional growth (Chiesa 2016, 2019).

The results of the study by Foruzanmehr and Vellinga indicate that wind catchers are only one of several measures for achieving temperature reduction: unsurprisingly, residents are often aware only of 'modern' solutions with respect to 'comfort, convenience and cleanliness' (Foruzanmehr and Vellinga 2011,283). I offer a comparison here. If drivers were asked whether they thought all concrete and paved roads were necessary in light of the high costs for construction and maintenance, they would probably answer as follows: it is necessary to consider the economic fact that unpaved roads massively accelerate vehicles' wear and tear. Drivers would not respond by saying that roads need to be built, materials have to be produced, exhausted materials have to be disposed of, and roads result in the sealing of huge areas, which has global consequences. It is necessary to consider social and cultural attributes in addition to economic and environmental factors. Arguments about the economic inefficiency of historical measures (Foruzanmehr and Vellinga 2011, 282) should be balanced against the full costs of energy production, including production and disposal of air-conditioners and all structural and building physical requirements.

I return to AlSayyad and Arboleda: 'As indigenous vernacular dwellings are designed for a stable climate, they are far more vulnerable to unpredictable climate fluctuations' $(2011,145)$. 'Far more' obviously signals a comparison with contemporary architecture. With ever-shorter intervals, we are confronted with news about contemporary architecture being inadequate despite predictable climate phenomena. I have difficulty understanding the authors' conclusion: 'The paradigm of climate responsiveness in the indigenous vernacular has been deeply disturbed ... 
by changing climate patterns which make traditional materials and dwellings inefficient.' (146) That quote immediately follows the assumption of grown tolerance to poor climate conditioning: 'Take the case of Salvadorian rural communities living nowadays in tiny metallic shelters that feel so hot on the inside they have been popularly dubbed as microwaves.' (AlSayyad and Arboleda 2011, 146) It is difficult to follow AlSayyad and Arboleda in their argumentation. People recently have become more tolerant to hardly bearable climate conditioning while they shall have lost all confidence in materials and dwellings they have coordinated for centuries.

I agree with AlSayyad and Arboleda that previously applied socioeconomic advantages are no longer valid. However, I would like to offer an example to trigger debate as to whether new socioeconomic factors can come into play. Cooperation and neighbourhood assistance are sociopolitical activities that can ultimately have socioeconomic consequences. To make construction more easily affordable and in keeping with highly valued ideals, architects have repeatedly tried initiating or supporting cooperative projects among residential communities. Cooperation as answer to common residential ideas bonds a group of people socially. It is difficult to imagine that experience with traditional vernacular constructions and styles of living offer no enlightenment.

The fourth topic addressed adaptability. I do not argue against all selected examples of AlSayyad and Arboleda that intend to prove that flexibility, expansion, and portability are no longer possible. Rapid population growth and social change in traditional societies are definitely facts that 'tend to challenge the theoretical adaptability of indigenous vernacular buildings' (148). I do not agree with this fundamental position. The examples presented by AlSayyad and Arboleda appear striking, but they do not appear to be correct in all cases. The Hakka people in Fujian Province built fortified dwellings also of rectangular shape, not only round. The Dong people also extend their houses in transverse direction (Zwerger 2006, 2013), not only lengthwise. Likewise, the Dong installed an additional fireplace, which defined a separate kitchen. It became a focal point for a son's family if it was impossible to erect an own house. The term 'adaptability' does not imply effortless change. To raise silkworms in the $19^{\text {th }}$ century, some Japanese farmers modified their house roofs (e.g., Kawashima 1973). Accordingly, the thatched structures had to be reroofed at regular intervals. Thus, the change in roof shape was not really a major challenge.
I here introduce Røstvik's idea as an antithesis to the conviction of AlSayyad and Arboleda that adaptability is an outdated term. Røstvik presents an example from Norway, which demonstrates how necessary it is to rethink the connotations with vernacular architecture. According to Røstvik, a number of affordable row houses built in wood 'boasted the typical hallmarks of sustainable design such as low energy and high efficiency'. But the houses were not designed universally. 'The wisdom of universal design, exemplified by the loose-fit, foresees a building's use and reuse for generations and hence, its structural and cultural durability.' (Røstvik 2011, 178) Two characteristics emerge as attributable to former vernacular architecture: longevity; and local design as not (yet) applicable in contemporary buildings. To ensure durability today, a design should be defined as little as possible. Less strictly defined designs could keep architecture adaptably. Lawrence agrees with Røstvik: 'Today, the principle of adaptability is too easily forgotten by architects, town planners and public officials who want to demolish, rather than renovate existing buildings [for the sake of economical calculations having only in mind the annual revenue / author's comment]. It should be noted that the vernacular buildings were rarely made redundant as quickly as many buildings designed by architects during the $20^{\text {th }}$ century.' $(2006,123)$

Vellinga observes a tendency in presentation and mediation whereby 'generalised models of environmentally responsive and sustainable architecture' are offered as development patterns toward incorporating them into current architectural practice $(2013,580)$. He is irked especially by the appropriation of vernacular architecture as an architecture of inherent superior qualities (Vellinga 2013). At this point, we encounter again the discussion about Rudofsky's alleged presentation of vernacular architecture.

All architectural history targets only highlights-examples that have survived owing to their extraordinary quality. No one would therefore conclude that all buildings possess the same quality. This may be one of the reasons for vernacular architecture having remained ignored for such a long time. Initially, building researchers had to demonstrate that non-elite architecture was capable of surviving for centuries. I will introduce here a comparison. Historiography has long presented individuals with superior qualities. Comparatively late, it was observed in that field that presenting the details of everyday life and the history of ordinary people had considerable power. This does not mean that all former historiography was wrong: quite the contrary, its critical analysis allowed the 
filtering out of correct narratives toward evaluating them and inferring conclusions about their categorisation. Still more important is the possibility of writing a comprehensive history of the collection of narratives, which need to be constantly reassessed beyond ideological attitudes and convictions.

I present here an additional critical comment. Vellinga's critique of essentialist and reductionist statements is welcome. However, he himself proves how easy it is to fall into a trap: 'It is notable that the various building traditions discussed are commonly presented in a generalised and essentialist manner' ${ }^{3}(2013,582)$. In his endeavour to stand up to false allegations, Vellinga is willing to employ oxymora. His request to take studies into account 'that focus on ... emerging traditions' $(2006,83)$ leaves no doubt about the author's intention. Tradition 'is the traditum, that which has been and is being handed down or transmitted' (Shils 1981, 12; cf. Bourdier and AlSayyad 1989, 6, who restrict the term's applicability to common people). It is possible only to transmit existing or past knowledge, not emerging knowledge that is still in a state of genesis.

\section{Vernacular Architecture as a Task of Reflection and Action}

Vellinga wavers from a programmatic title, 'The End of the Vernacular' $(2006,93 ; 2011)$, to hopeful conclusions that vernacular architecture could teach lessons (2006, 83 and 92-93; 2013, 585). This is, however, not necessarily a contradiction. I would suggest that the current, increasingly sophisticated, detailed examinations as to why the connotations of historical vernacular architecture are simplified, single-minded, wrong, and outdated. Various contributions have clarified the enormous shortcomings in earlier and many current academic contributions. It is necessary to understand that a simple adaptation of former knowledge and practices and 'restricting our focus to environmental issues only' (Vellinga 2015,5) is not appropriate for current needs. However, all analyses demonstrating deficits remain intellectual exercises if no effort is made to redefine 'vernacular architecture' in all its manifestations. If one paraphrases Upton's 'restirring the pot' (2006/07, 11 ), it is necessary to question where and how to start redefinition. It becomes necessary to question the statement of Herz whereby, 'In contemporary times of globalisation ... vernacular architecture takes on an entirely new role. It is strategically employed to blend over differences, and to cloak and hide changes occurring in contemporary societies. An apolitical architecture is transformed into a depoliticising architecture' $(2008,271)$.
For long, constant, but hardly realisable, adaptation to changing conditions was a characteristic feature of vernacular architecture. Streams of refugees or waves of emigration took with them distinctive building elements as part of their cultural identity. The urbanisation boom induced a more drastic change. The previous construction of housing by landowners or through experienced builders no longer became possible. Larger residential houses have now become technically so complex that only professional builders can construct them. New building techniques have to be learned and tested, and they include aberrations. It is improbable that satisfactory results could have been developed in the course of a few years.

I mentioned earlier the discontent among many inhabitants with their modern living environment. Such opinions could be dismissed as complaints despite residents enjoying high standards of living. However, some scholars share those perceptions. 'Housing modernisation has, especially in the case of low-cost housing, led to the disappearance of qualities of utility characteristic of traditional dwellings. For the poor, the transition has in many respects meant change for the worse, not, as anticipated, for the better.' (Larsson 1989, 503) Bourdier states that in Third World countries there is an imperative to solve the paradox of how to benefit from modernisation while returning to the wisdom of non market-dependent values' $(1989,35)$. That sentence contains a political challenge with respect to 'benefit' and 'returning': it is less a paradox than a basis for discussion. Further, we might ask whether Bourdier's statement might not also apply to the First World. Doubtless the search for an answer to that question would be more tedious and probably more painful. According to Mugerauer, it has to be accepted as a fact that internationalised construction technologies 'tend to displace and ignore local identities and senses of place' (95). Here, again, the arguments can be dismissed as additional voices to the chorus of complaints attacking modern architecture or-worse-'Western' buildings 'valued as symbols of modernity' (borrowing words from Brown and Maudlin 2012, 349). However, the breathtakingly rapid changes in requirements for housing production need time for development. That time seems to have run short.

Like resource scarcity, climate change remains a major challenge, although those two are not the only ones. Contemporary architecture has to find answers as deep social changes become evident in the following ways: new family structures and household types; new relationships with respect to residence and work; new mobility plans; new technologies; and other changes that affect dwellings and 
the meaning of living space. Time will tell whether future social challenges will interfere with our lives as deeply as the change to sedentariness has done.

Contemporary architectural research contends with a great problem. It appears to be overly focused on offering technological solutions. The current research of Zhai and Previtali is a striking example (2019). Apart from this critique, the search for globally valid design rules reflects insufficient understanding about the complex interdependent situations that demand action. Of course, it is to be expected that broader recognition will be accorded to a global project than to a local one. However, it is necessary to question architectural designs that aim to equalise completely different climatic or topographic conditions by relying on technology. The idea behind such projects is the wish to offer the most economic solution. But it is imperative to avoid purchasing practices that strive for the cheapest option irrespective of any hidden costs. It is necessary to look in advance for possible later unwanted consequences.

Too many architects and urban planners have become accustomed to 'the "one problem-one solution" method' (Lawrence 2006, 124). According to Lawrence (2006) 'academics, policy decision-makers and city planners have ignored ... complexity, especially the web of economic, ecological, health and other social characteristics of the built environment'. Such statements express awareness of the urgency of the problem. This urgency demands unconventional ideas in finding solutions. Magazines and books present presumed best-practice examples. But it is necessary to analyse them carefully. Ingersoll states that for decades, architects attempted to build more environmentfriendly structures. Strikingly, most architecture classified publicly as environment-friendly has been directed at prestige projects designed by famous architects. At least some of them allow 'a strong doubt ... that the high cost of construction can be amortised by good energy performance' (Ingersoll 2012, 582 quoting McDonough and Braungart). Other structures comply with the principles of biomimicry significantly less than with economic costbenefit calculations (Ingersoll 2012, 586-587). Ingersoll sees only one solution. Future-oriented projects that meet the needs of larger population groups living in vernacular architecture have one common ground: waiver. 'Waiver' here refers to refraining from constructing buildings that would have special status, such as with respect to the constructed area or size (Ingersoll 2012, 584). Ingersoll is not alone. Sauerbruch and Hutton $(2011,41)$ reword his intention seemingly less strictly when talking of 'reduction in demand and technological innovation'. 'Reduction in demand' is in conflict with all efforts of the economic system, which is focused on constant growth; that system is eager to make people believe that such growth is the only guarantor that civilisation will continue. The demands of growth have to clearly address the counterclaims of waiver if the doctrine of unreflected growth should be questioned.

Technology can and must provide support such that the concept of waiver is not perceived as a loss but as a profit in the best case. It should become a political challenge to detach waiver from its connotation of material goods. Waiver should be offered to the general public as a way for reflecting how it could be possible for all humankind to live a good life-both now and in a future with a huge world population. The alternative way out of our current dilemma would be a decreed change. Authoritarian scenarios incite opposition. Only insight allows people to overcome inertia and engage in radical thoughts. Global problems cannot be solved by a single brilliant idea. 'While global warming seems single minded in its course, there need to be many answers to the Ecology Question. Different places offer different potentials.' (Ingersoll 2012, 589). Røstvik (2011, 173) believes that smaller, lighter buildings are necessaryas well as 'an aesthetic of efficiency not only in terms of energy consumption, but also in terms of how architecture is conceived, designed, constructed, demolished and recycled' (174). Thus, Røstvik believes that possible approaches to efficiency are the architect's responsibility.

I believe that responsibility should be shared-among both consumers and politicians. Contemporary vernacular architecture can be sustainable (and this is another prospective challenge) only if it serves its users' needs. At present, there are two divergent views. On the one hand, there are people who have experienced a certain measure of convenience with respect to their living space, and they are not willing to relinquish that. This disposition is illustrated by the example cited above about air-conditioners replacing wind catchers ${ }^{4}$. On the other hand, there are political actors who are obliged to convince their voters that radical revisions in habits are inevitable. There is a need for politicians to have the courage to tell people that their choices may be neither easy to explain or understand.

\section{Conclusion}

I quote here Shil's (1981) explanation of the term 'tradition': 'The tradition of empirical knowledge embraced both the knowledge of how to adapt an inherited model of a tool or a machine so that it would be appropriate to 
the better performance of recurrently given tasks and the knowledge of how to use the tool efficiently' $(1981,83)$. Tradition based on empirical knowledge enables progress. If actions are taken without any handed-down knowledge, the results occur by chance: without incorporating a knowledge of history, the probability of success is low. Indeed, traditional thought encourages innovation: 'Mastery of traditional empirical knowledge is ... capable ... of becoming detached from the tradition through efforts to see how work could be done more efficiently.' (84) In addition, 'It is the tradition which permits the discernment of the opening to invention.' (85) Vernacular architecture thus should be discussed as a source of understanding values of tradition 'as a creative, adaptive and reflective process within modernity' (Brown and Maudlin 2012, 349, referring to several other authors).

Returning to Alexander's leitmotiv presented in the Introduction, I share the critical view of AlSayyad and Arboleda about the 'indissoluble connection of vernacular architecture, sustainability and timelessness. However, I wish to bring those terms together in a new context. If vernacular architecture is regarded as the type of housing for most of the world's population, it is clear that it has to serve many similar tasks for many people; those tasks are the same as those for people who previously lived in villages. In addition, there are social and cultural tasks. But people face additional, entirely new challenges. It is necessary to deal with the consequences of excessively long and reckless lack of considering relationships between housing, building, nature and human needs. As a result, the concept of sustainability inevitably appears. The key issue is not about proving whether 'old vernacular architecture' is more sustainable than 'emerging vernacular architecture': it is about how efforts should be made to rethink building and building processes anew toward making tomorrow's constructions accord with today's standards of responsibility. People need to rethink what they need for living. Only after having become aware of their dependence from resources they can consider how they wish to live (not least with respect to social and cultural conditions). This condition is timeless.

My answers to the three questions posed in the Introduction may appear unsatisfactory: they may seem provocative to some people, utopian to others. I regard them as contributing to the general discussion. I am convinced that vernacular architecture has become a difficult concept, one subject to many conditions, influences, and interests; thus, all efforts to provide straight answers fall short.

\section{Notes}

1. Even though there exist surprising examples for the opposite. The reintroduction of the Japanese yariganna in $20^{\text {th }}$ century demonstrates that sufficient image material and ambition can revive a lost technique.

2. There is insufficient space to discuss the complex interplay of better health care leading to an increasing population, which in turn leads to shorter cycles of crop rotation, further penetration of the majority population into minority settlement areas, imported or supported poppy cultivation, instrumentalisation for power struggles, and war games (e.g., McCaskill and Kampe 1997).

3. The English term 'commonly' has two meanings: often and usually. If Vellinga intended the meaning 'often', I retract my critique! 'Usually' would be an inadmissible generalisation.

4. It is highly interesting to extend the discussion by comparing the results of Foruzanmehr and Vellinga with those of an investigation by Azarbayjani (2019) on the same topic.

\section{References}

Aalen, Frederick H. A. 1973. "Vernacular Architecture of the British Isles." Yearbook of the Association of Pacific Coast Geographers 35, 27-48.

Alexander, Christopher. 1979. The Timeless Way of Building. New York: Oxford University Press.

AlSayyad, Nezar. 1989. “Epilogue." In Dwellings, Settlements and Tradition, edited by Jean-Paul Bourdier and Nezar Alsayyad, 527-532. Lanham, New York, London: University Press of America.

AlSayyad, Nezar. 2001. "Global Norms and Urban Forms in the Age of Tourism: Manufacturing Heritage, Consuming Tradition." In Consuming Tradition, Manufacturing Heritage, edited by Nezar AlSayyad, 1-33. London: Routledge.

AlSayyad, Nezar and Gabriel Arboleda. 2011. "The Sustainable Indigenous Vernacular: Interrogating a Myth." In Aesthetics of Sustainable Architecture, edited by Sang Lee, 134-151. Rotterdam: 010 Publishers.

Azarbayjani, Mona. 2019. "Seeking Contemporary Urban Comfort Through Vernacular Architectural Principles in Hot Arid Climate." In Sustainable Vernacular Architecture. How the Past can Enrich the Future, edited by Ali Sayigh, 93-104. Cham: Springer International Publishing.

Berkes, Fikret. (1999) 2018. Sacred Ecology. New York, 
London: Routledge.

Bourdier, Jean-Paul. 1989. "Reading Tradition." In Dwellings, Settlements and Tradition, edited by Jean-Paul Bourdier and Nezar Alsayyad, 35-52. Lanham, New York, London: University Press of America.

Bourdier, Jean-Paul and AlSayyad, Nezar. 1989. "Prologue." In Dwellings, Settlements and Tradition, edited by Jean-Paul Bourdier and Nezar Alsayyad, 5-26. Lanham, New York, London: University Press of America.

Brown, Robert and Daniel Maudlin. 2012. "Concepts of Vernacular Architecture." In The SAGE Handbook of Architectural Theory, edited by Greig Crysler, Stephen Cairns, and Hilde Heynen, 340-354. Los Angeles: SAGE Publications.

Brunskill, Ronald William 1971. Illustrated Handbook of Vernacular Architecture. London: Faber \& Faber.

Cairns, Malcolm ed. 2007. Voices from the Forest. Integrating Indigenous Knowledge into Sustainable Upland Farming. Washington: Resources for the Future Press.

Chiesa, Giacomo. 2016. "Geo-climatic Applicability of Evaporative and Ventilative Cooling in China." International Journal of Ventilation 15 (3-4): 205-219.

Chiesa, Giacomo. 2019. "Early Design Strategies for Passive Cooling of Buildings: Lessons Lerned from Italian Archetypes." In Sustainable Vernacular Architecture. How the Past can Enrich the Future, edited by Ali Sayigh, 377-408. Cham: Springer International Publishing.

Chiesa, Giacomo and Mario Grosso. 2016. "Breakthrough of Natural and Hybrid Ventilative Cooling Technologies: Models and Simulations." International Journal of Ventilation 15 (3-4): 183-185.

Choocharoen, Chalathon. 2014. "Recording, Validating and Scaling up Local Ecological Knowledge of Ethnic Minority Farmers in Northern Thailand and Northern Laos." PhD diss., University of Hohenheim, Germany.

Foruzanmehr, Ahmadreza and Marcel Vellinga. 2011. "Vernacular Architecture: Questions of Comfort and Practicability." Building Research \& Information 39 (3), 274-285.

Guidoni, Enrico. (1979) 1994. Architecture Primitive. Milano: Gallimard/Electa.

GRI (The Getty Research Institute). 2018. "Getty Vocabularies." Accessed December 1, 2018. https://www.getty. edu/research/tools/vocabularies/

Hamza, Neveen. 2019. "Contested Legacies: Architecture Between Sustainability and the Exotic." In Sustainable Vernacular Architecture. How the Past can Enrich the
Future, edited by Ali Sayigh, 7-21. Cham: Springer International Publishing.

Hecht, Susanna B., Kathleen D. Morrison, and Christine Padoch, eds. 2014. The Social Lives of Forests: Past, Present, and Future of Woodland Resurgence. Chicago, London: The University of Chicago Press.

Herz, Manuel. 2008. "The Vernacular - Or: Towards a New Brutalism." In Architecture and Identity, edited by Peter Herrle and Erik Wegerhoff, 271-279. Berlin: LIT Verlag.

Illich, Ivan. 1982. Gender. New York: Pantheon.

Ingersoll, Richard. 2012. "The Ecology Question and Architecture." In The SAGE Handbook of Architectural Theory, edited by Greig Crysler, Stephen Cairns, and Hilde Heynen, 573-589. Los Angeles: SAGE Publications.

Isaac, Morna and van Detlef Vuuren. 2009. "Modeling Global Residential Sector Energy Demand for Heating and Air Conditioning in the Context of Climate Change." Energy Policy 37 (2): 507-521.

Kawashima, Chuji. 1973. Horobiyuku minka - yane gaikan [Perishing Private House-Roof and Exterior]. Tokyo.

Kopytoff, Igor. 1986 (2003). "The Cultural Biography of Things: Commoditization as Process." In The Social Life of Things-Commodities in Cultural Perspective, edited by Arjun Appadurai, 64-91. Cambridge: Cambridge University Press.

Larsson, Anita. 1989. "Traditional Versus Modern Housing in Botswana-An Analysis from the User's Perspective." In Dwellings, Settlements and Tradition, edited by Jean-Paul Bourdier and Nezar Alsayyad, 503-526. Lanham, New York, London: University Press of America.

Lawrence, Roderick J. 2006. "Learning from the Vernacular: Basic Principles for Sustaining Human Habitats." In Vernacular Architecture in the Twenty-First Century, edited by Lindsay Asquith and Marcel Vellinga, 110127. London, New York: Taylor \& Francis.

Leach, Neil. 1998 (2002). "The Darkside of the Domus." In What is Architecture? edited by Andrew Ballantyne, 88-102. London: Routledge.

Lewcock, Ronald. 2006. “'Generative Concepts' in Vernacular Architecture." In Vernacular Architecture in the Twenty-First Century, edited by Lindsay Asquith and Marcel Vellinga, 199-214. London, New York: Taylor \& Francis.

Logue, J. M., M. H. Sherman, I. S. Walker, and B. C. Singer. 2013. "Energy Impacts of Envelope Tightening and Mechanical Ventilation for the U. S. Residential 
Sector." Energy and Buildings 65, 281-291.

Maudlin, Daniel. 2010. “Crossing Boundaries: Revisiting the Thresholds of Vernacular Architecture." Vernacular Architecture vol. 41: 10-14.

McCaskill, Don, and Ken Kampe. 1997. Development or Domestication? Indigenous Peoples of Southeast Asia. Chiang Mai: Silkworm Books.

Mugerauer, Robert. 2001. "Openings to Each Other in the Technological Age.” In Consuming Tradition, Manufacturing Heritage, edited by Nezar AlSayyad, 90-110. London: Routledge.

Noble, Allen G. 2007. Traditional Buildings: A Global Survey of Structural Forms and Cultural Functions. London, New York: I. B. Tauris.

Oliver, Paul. 1975. "Introduction.” In Shelter, Sign \& Symbol, edited by Paul Oliver, 7-37. London: Barrie \& Jenkins.

Oliver, Paul. 1987. Dwellings: The House across the World. Oxford: Phaidon.

Oliver, Paul. 1989. "Handed down Architecture: Tradition and Transmission." In Dwellings, Settlements and Tradition, edited by Jean-Paul Bourdier and Nezar Alsayyad, 53-75. Lanham: University Press of America.

Oliver, Paul. 2001. "Re-Presenting and Representing the Vernacular: The Open-Air Museum.” In Consuming Tradition, Manufacturing Heritage, edited by Nezar AlSayyad, 191-211. London: Routledge.

Özkan, Suha. 2006. "Traditionalism and Vernacular Architecture in the Twenty-first Century.” In Vernacular Architecture in the Twenty-First Century. Theory, Education and Practice, edited by Lindsay Asquith and Marcel Vellinga, 97-109. London, New York: Taylor and Francis.

Parrotta, John and Ronald Trosper, eds. 2012. Traditional Forest-Related Knowledge. Sustaining Communities, Ecosystems and Biocultural Diversity. Dordrecht: Springer.

Rapoport, Amos. 1980. "Vernacular Architecture and the Cultural Determinants of Form." In Buildings and Society, edited by Anthony King, 283-305. London: Routledge and Keegan Paul.

Rapoport, Amos. (1982) 1990. The Meaning of the Built Environment. Tucson: The University of Arizona Press.

Rapoport, Amos. 1989. “Attributes of Tradition.” In Dwellings, Settlements and Tradition, edited by Jean-Paul Bourdier and Nezar Alsayyad, 77-105. Lanham, New York, London: University Press of America.

Robinson, Mike. 2001. “Tourism Encounters: Interand Intra-Cultural Conflicts and the World's Largest
Industry." In Consuming Tradition, Manufacturing Heritage, edited by Nezar AlSayyad, 34-67. London: Routledge.

Røstvik, Harald N. 2011. "The Vernacular, the Iconic and the Fake." In Aesthetics of Sustainable Architecture, edited by Sang Lee, 168-178. Rotterdam: 010 Publishers.

Rudofsky, Bernard. 1964. Architecture without Architects. New York: Doubleday \& Company.

Sauerbruch, Matthias, and Louisa Hutton. 2011. "What Does Sustainability Look Like?" In Aesthetics of Sustainable Architecture, edited by Sang Lee, 41-49. Rotterdam: 010 Publishers.

Scott, James C. 2009. The Art of Not Being Governed. New Haven, London: Yale University Press.

Shils, Edward. 1981. Tradition. The University of Chicago Press.

Tuan, Yi-Fu. 1989. “Traditional: What Does It Mean?” In Dwellings, Settlements and Tradition, edited by JeanPaul Bourdier and Nezar Alsayyad, 27-34. Lanham, New York, London: University Press of America.

Upton, Dell. 1983. “The Power of Things: Recent Studies in American Vernacular Architecture." American Quarterly 35 (3): 262-279.

Upton, Dell. 1993. “The Tradition of Change." Traditional Dwellings and Settlements Review 5 (1): 9-15.

Upton, Dell. 2006/2007. “The VAF at 25: What Now?” Perspectives in Vernacular Architecture 13 (2): 7-13.

Vellinga, Marcel. 2006. "Engaging the Future. Vernacular Architecture Studies in the Twenty-first Century." In Vernacular Architecture in the Twenty-First Century. Theory, Education and Practice, edited by Lindsay Asquith and Marcel Vellinga, 81-94. London, New York: Taylor and Francis.

Vellinga, Marcel. 2011. "The End of the Vernacular. Anthropology and the Architecture of the Other." Etnofoor 23 (1): 171-192.

Vellinga, Marcel. 2013. “The Noble Vernacular.” In The Journal of Architecture 14 (8): 570-590.

Vellinga, Marcel. 2015. "Vernacular Architecture and Sustainability: Two or Three Lessons ...” In Vernacular Architecture: Towards a Sustainable Future, edited by C. Mileto, F. Vegas, L. García Soriano, and V. Cristini, 3-8. Boca Raton: CRC Press.

Wiens, Herold J. 1954. China's March toward the Tropics: A Discussion of the Southward Penetration of China's Culture, Peoples, and Political Control in Relation to the Non-Han-Chinese Peoples of South China and in the Perspective of Historical and Cultural Geography. 
Hamden, Conn.: The Shoe String Press.

Yokoyama, Satoshi, K. Okamoto, C. Takenaka, and I. Hirota, eds. 2014. Integrated Studies of Social and Natural Environmental Transition in Laos. Tokyo: Springer. Zhai, Zhiqiang, and Jonathan M. Previtali 2010. "Ancient Vernacular Architecture: Characteristics Categorization and Energy Performance evaluation." Energy and Buildings 42, 357-365.

Zwerger, Klaus. 2006. Vanishing Tradition: Architecture and Carpentry of the Dong Minority in China. Bangkok: Orchid Press.

Zwerger, Klaus. 2012. Wood and Wood Joints: Building Traditions in Europe, Japan and China. Basel: Birkhäuser.

Zwerger, Klaus. 2013. Die Architektur der Dong [The Architecture of Dong]. Wien: Schlebrügge.

Zwerger, Klaus, and Mallikamarl Suchon. 2019. "Vernacular Architecture in Northern Laos.” In Vernacular Architecture-Atlas for Living Throughout the World, edited by Christian Schittich, 228-239. Basel: Birkhäuser. 